\title{
The Many Faces of Rare Earth Carbodiimide Compounds
}

\begin{tabular}{|r|l|}
\hline Journal: & Zeitschrift für Anorganische und Allgemeine Chemie \\
\hline Manuscript ID: & zaac.200900221.R1 \\
\hline Wiley - Manuscript type: & Article \\
\hline Date Submitted by the \\
Author: & $13-$ May-2009 \\
\hline Complete List of Authors: & Meyer, Hans-Juergen \\
\hline Keywords: & Rare earth, Carbodiimide, Fluoride, Metathesis \\
\hline
\end{tabular}

\section{s scholaroNE \\ Manuscript Central}




\title{
The Many Faces of Rare Earth Carbodiimide Compounds
}

\author{
Leonid Unverfehrt, Markus Ströbele, Jochen Glaser, and H.-Jürgen Meyer* \\ Dedicated to Professor Martin Jansen on the Occasion of his 60th Birthday
}

Keywords: Rare earth; Fluoride; Carbodiimide; Metathesis

\begin{abstract}
Solid state metathesis reactions have been established as a successful tool in syntheses of rare earth carbodiimide compounds. Current results evidence the new compounds $\operatorname{LiRE}\left(\mathrm{CN}_{2}\right)_{2}$ with $\mathrm{RE}=\mathrm{La}, \mathrm{Ce}$ and the carbodiimide nitride $\mathrm{Ce}_{3}\left(\mathrm{CN}_{2}\right)_{3} \mathrm{~N}$. $\operatorname{LiRE}\left(\mathrm{CN}_{2}\right)_{2}$ compounds were synthesized by solid state metathesis reactions between $\mathrm{REF}_{3}$ and $\mathrm{Li}_{2}\left(\mathrm{CN}_{2}\right)$ in $1: 2$ molar ratio. $\mathrm{Ce}_{3}\left(\mathrm{CN}_{2}\right)_{3} \mathrm{~N}$ was obtained via thermal conversion of $\mathrm{LiCe}\left(\mathrm{CN}_{2}\right)_{2}$.

Crystal structures of $\mathrm{LiLa}\left(\mathrm{CN}_{2}\right)_{2}$ and $\mathrm{Ce}_{3}\left(\mathrm{CN}_{2}\right)_{3} \mathrm{~N}$ were determined from X-ray single crystal data (LiLa(CN $)_{2}: P 2_{1} / m, a=542.4(2) \mathrm{pm}, b=379.16(7) \mathrm{pm}, c=1013.0(3) \mathrm{pm}, \beta=101.35(3)$ o; $\left.\mathrm{Ce}_{3}\left(\mathrm{CN}_{2}\right)_{3} \mathrm{~N}: P 22_{1} 2_{1}, a=672.97(9) \mathrm{pm}, \quad b=1309.8(2) \mathrm{pm}, c=1697.7(3) \mathrm{pm}\right)$ and $\mathrm{LiCe}\left(\mathrm{CN}_{2}\right)_{2}$ was assigned from indexed X-ray powder diffraction data $\left(\mathrm{LiCe}\left(\mathrm{CN}_{2}\right)_{2}\right.$ : $a=$ 541.9(1) pm, $\left.b=374.50(8) \mathrm{pm}, c=1008.8(2) \mathrm{pm}, \beta=101.21(1)^{\circ}\right)^{\circ}$.
\end{abstract}

The crystal structure of $\mathrm{LiLa}\left(\mathrm{CN}_{2}\right)_{2}$ represents a layer-like arrangement of ions as typical for this type of compounds. The crystal structure of $\mathrm{Ce}_{3}\left(\mathrm{CN}_{2}\right)_{3} \mathrm{~N}$ reveals chains of $\left[\mathrm{NCe}_{4}\right]$ tetrahedra running parallel to each other, and trigonal prismatic to trigonal antiprismatic arrangements of six distinctly interconnected $\left[\mathrm{Ce}_{3}-\mathrm{NCN}-\mathrm{Ce}_{3}\right]$ units. Both structures contain $\left(\mathrm{CN}_{2}\right)^{2-}$ ions deviating from their ideal $\mathrm{D}_{\text {on }}$ symmetry, with $\mathrm{C}-\mathrm{N}$ distances ranging between 121 and $126 \mathrm{pm}$ and $\mathrm{N}-\mathrm{C}-\mathrm{N}$ angles near $180^{\circ}$.

* Prof. Dr. H.-J. Meyer

E-mail: juergen.meyer@uni-tuebingen.de

[a] Abteilung für Festkörperchemie und Theoretische Anorganische Chemie Institut für Anorganische Chemie

Ob dem Himmelreich 7

Eberhard-Karls-Universität Tübingen

D-72074 Tübingen, Germany 


\section{Introduction}

Rare earth $(\mathrm{RE})$ carbodiimides are an emerging and rapidly growing group of compounds. Dioxide monocarbodiimides were reported in 1994 presumably synthesized under fortuitous conditions with the aid of a graphite container serving as a carbon source for the carbodiimide ion of $\mathrm{La}_{2} \mathrm{O}_{2}\left(\mathrm{CN}_{2}\right)$ [1]. Two distinct structures are reported for $\mathrm{RE}_{2} \mathrm{O}_{2}\left(\mathrm{CN}_{2}\right)$. Tetragonal $\mathrm{La}_{2} \mathrm{O}_{2}\left(\mathrm{CN}_{2}\right)$ is reported to contain axially-parallel disordered $[\mathrm{N}=\mathrm{C}=\mathrm{N}]^{2-}$ ions, whereas in trigonal $\mathrm{RE}_{2} \mathrm{O}_{2}\left(\mathrm{CN}_{2}\right)$ with $\mathrm{RE}=\mathrm{Ce}-\mathrm{Gd}$, Dy, Ho, $\mathrm{Er}, \mathrm{Tm}, \mathrm{Yb}[2,3]$ the alignment of $[\mathrm{N}=\mathrm{C}=\mathrm{N}]^{2-}$ ions follows the threefold axis.

A great deal of rare earth carbodiimide or infrequently cyanamide compounds was synthesized following solid state metathesis reactions between rare earth trihalides and lithium carbodiimide. Upon heating these mixtures, solid state metathesis reactions reveal their characteristics, with an ignition coming about in a temperature regime around 450 to $550{ }^{\circ} \mathrm{C}$ when double exchange of ions is being completed. A flux can be used in reactions to lower the reaction temperature and to improve the crystal growth of products.

A series of quasi-binary carbodiimides $\mathrm{RE}_{2}\left(\mathrm{CN}_{2}\right)_{3}$ [4-6] with trivalent rare earth ions $(\mathrm{RE}=\mathrm{Y}-$ $\mathrm{Lu}$, except Pm, La) has been established by this route as well as some families of multinary carbodiimides (or in some cases cyanamides) represented by the formulas $\operatorname{REX}\left(\mathrm{CN}_{2}\right)(X=$ $\mathrm{Cl}, \mathrm{F})[7,8], \mathrm{RE}_{2} \mathrm{X}\left(\mathrm{CN}_{2}\right) \mathrm{N}(\mathrm{X}=\mathrm{Cl}, \mathrm{Br}, \mathrm{I})[9,10], \mathrm{ARE}_{2} \mathrm{X}_{3}\left(\mathrm{CN}_{2}\right)_{2}(\mathrm{~A}=\mathrm{Li}, \mathrm{X}=\mathrm{F})$, and two more compositions being reported in this work.

Carbodiimides or cyanamides containing divalent europium ions were obtained for $\mathrm{Eu}\left(\mathrm{CN}_{2}\right)$ [11] through high temperature reactions, and through halide-based flux reactions for a number of multinary europium compounds [12].

The synthesis of new rare earth compounds containing nitrides or carbodiimides has received considerable attention due to the luminescence properties of doped compounds and their potential in solid state lightning, but also for other perspectives. The luminescence behaviour of lanthanide-doped carbodiimide compounds has been studied for $\mathrm{RE}_{2} \mathrm{O}_{2}\left(\mathrm{CN}_{2}\right)$ : $\mathrm{Ln}$ [13] and $\mathrm{Y}_{2} \mathrm{O}_{2}\left(\mathrm{CN}_{2}\right)$ : $\mathrm{Eu}$ [14] in relation to the well-known red light emitter $\mathrm{Y}_{2} \mathrm{O}_{2} \mathrm{~S}$ :Eu. For compounds $\mathrm{Gd}_{2}\left(\mathrm{CN}_{2}\right)_{3}$ : $\mathrm{Ln}$ with $\mathrm{Ln}=\mathrm{Ce}$, $\mathrm{Tb}$ a broad yellow emission has been obtained. Furthermore, the dimorphic character of structures has been demonstrated for $\mathrm{Y}_{2} \mathrm{O}_{2}\left(\mathrm{CN}_{2}\right)$ and by pressure induced phase transition for $\operatorname{Tm}_{2}\left(\mathrm{CN}_{2}\right)_{3}$ [6].

Still there are some homologous examples of $\mathrm{RE}$ compounds missing in carbodiimide containing families. Some of them can be assumed isotypic and others have just not been attempted to make. A challenging example may be the missing compound $\operatorname{La}_{2}\left(\mathrm{CN}_{2}\right)_{3}$ [15].

The rational approach of solid state metathesis reactions has been successfully used as a conceptual tool for the discovery of some novel [16] compounds and turns out to be a promising endeavour in solid state synthesis. 


\section{Experimental Section}

\section{Synthesis of $\mathrm{Li}_{2}\left(\mathrm{CN}_{2}\right)$}

$\mathrm{Li}_{2}\left(\mathrm{CN}_{2}\right)$ was prepared via reaction of $700 \mathrm{mg}$ (ca. $20 \mathrm{mmol}$ ) $\mathrm{Li}_{3} \mathrm{~N}$ (Alfa Aesar, $99.5 \%$ ) with an excess of $1400 \mathrm{mg}$ (ca. $11 \mathrm{mmol}$ ) melamine (Fluka, >99\%, purum) [17] following the reaction equation:

$$
2 \mathrm{Li}_{3} \mathrm{~N}+\mathrm{C}_{3} \mathrm{~N}_{3}\left(\mathrm{NH}_{2}\right)_{3} \rightarrow 3 \mathrm{Li}_{2}\left(\mathrm{CN}_{2}\right)+2 \mathrm{NH}_{3}
$$

The reaction mixture was carefully homogenized in an agate mortar under argon atmosphere (glove box) and placed into a silver boat. An argon flooded transfer shuttle was used to replace the silver boat from the glove box into a silica tube, being inserted into the silica tube under nitrogen counter current.

The reaction mixture was heated up (ca. $10^{\circ} \mathrm{C} / \mathrm{min}$ ) in a silica tube under nitrogen flow (ca. $200 \mathrm{ml} / \mathrm{min}$ ) to $270{ }^{\circ} \mathrm{C}$ and remained at this temperature for about ten minutes before it was further heated up very slowly $\left(1{ }^{\circ} \mathrm{C} / \mathrm{min}\right.$.) to $330{ }^{\circ} \mathrm{C}$. From $330{ }^{\circ} \mathrm{C}$ the temperature was further raised (10 ${ }^{\circ} \mathrm{C} / \mathrm{min}$.) to $600{ }^{\circ} \mathrm{C}$ to remove the excess of melamine from the product. Afterwards the reaction was allowed to cool down to room temperature and the crystalline powder was inspected by XRD.

The beginning of the reaction was obtained at $150{ }^{\circ} \mathrm{C}$, as indicated by the development of $\mathrm{NH}_{3}$ at the exhaust pipe of the silica tube. Note that faster heating-up rates may generate a strongly exothermic reaction when reaching temperatures near $270-300{ }^{\circ} \mathrm{C}$, thereby expelling material from the reaction vessel. If $\mathrm{Li}_{2} \mathrm{NH}$ was present in the product, the mixture was carefully ground with ca. $150 \mathrm{mg}$ melamine and heated $\left(5{ }^{\circ} \mathrm{C} / \mathrm{min}\right.$.) to $600{ }^{\circ} \mathrm{C}$. Preparations of $\mathrm{Li}_{2}\left(\mathrm{CN}_{2}\right)$ proceeded quantitatively and yielded a single phase product according to powder XRD.

\section{Synthesis of LiLa $\left(\mathrm{CN}_{2}\right)_{2}$ and $\mathrm{LiCe}\left(\mathrm{CN}_{2}\right)_{2}$}

Rare earth trifluorides $\left(\mathrm{REF}_{3}\right)$ were synthesized as previously reported [8]. Solid state metathesis reactions were performed between $\operatorname{REX}_{3}(X=\mathrm{F}, \mathrm{Cl})$ and $\mathrm{Li}_{2}\left(\mathrm{CN}_{2}\right)$. Reactions of $\mathrm{LaCl}_{3}$ (ABCR, $99.9 \%$ ) were carried out in flame sealed silica ampoules and reactions with trifluorides in copper ampoules $(4 \mathrm{~cm}$ long pieces, inner diameter ca. $5 \mathrm{~mm}$, thickness of the wall ca. $1 \mathrm{~mm}$, cleaned with $\mathrm{HCl}$ ). Copper tubes were sealed first from one side by arcmelting, loaded with starting materials under argon (glove box) and than sealed from the other side, before they were flame sealed into silica tubing.

Reaction containers were charged with $1: 2$ molar mixtures of $\operatorname{REX}_{3}(\mathrm{RE}=\mathrm{La}, \mathrm{Ce} ; \mathrm{X}=\mathrm{F}, \mathrm{Cl})$ and $\mathrm{Li}_{2}\left(\mathrm{CN}_{2}\right)$ under dry argon atmosphere inside a glove box. The reaction vessels were placed into a tube furnace and reacted at $450-650{ }^{\circ} \mathrm{C}$ for two days before they were allowed to cool down to room temperature. The course of reactions can be specified by the following equation: 


$$
\mathrm{REX}_{3}+2 \mathrm{Li}_{2}\left(\mathrm{CN}_{2}\right) \rightarrow \operatorname{LiRE}\left(\mathrm{CN}_{2}\right)_{2}+3 \mathrm{LiX}
$$

Reactions departing from $\mathrm{REF}_{3}$ yielded colourless powders of $\mathrm{LiLa}\left(\mathrm{CN}_{2}\right)_{2}$ and yellow powders of $\mathrm{LiCe}\left(\mathrm{CN}_{2}\right)_{2}$ at $500{ }^{\circ} \mathrm{C}$ besides coproduced $\mathrm{LiF}$. Reactions with $\mathrm{LaCl}_{3}$ and $\mathrm{Li}_{2}\left(\mathrm{CN}_{2}\right)$ yielded $\mathrm{LiLa}\left(\mathrm{CN}_{2}\right)_{2}$ in the temperature range $450-550{ }^{\circ} \mathrm{C}$. Product treatments of $\mathrm{LiCe}\left(\mathrm{CN}_{2}\right)_{2}$ and LiF above $650{ }^{\circ} \mathrm{C}$ gave rise to the decomposition into a crystalline product containing the new compound $\mathrm{Ce}_{3}\left(\mathrm{CN}_{2}\right)_{3} \mathrm{~N}$.

All compounds behave moderately stable in air and against hydrolysis. Reaction products were washed in water, dried with acetone, and inspected by powder XRD.

\section{X-Ray Powder Diffraction}

The XRPD patterns of the reaction products were collected with a Stadi-P (Stoe, Darmstadt) powder diffractometer using $\mathrm{Cu}-\mathrm{K}_{\alpha 1}$ radiation (germanium monochromator). No significant reflections of any side phase could be identified after indexing the patterns of $\operatorname{LiLa}\left(\mathrm{CN}_{2}\right)_{2}$ and $\mathrm{LiCe}\left(\mathrm{CN}_{2}\right)_{2}$ by using the program system WinXPow [18]. The patterns were indexed monoclinically with $a=541.5(2) \mathrm{pm}, b=378.2(2) \mathrm{pm}, c=1010.6(4) \mathrm{pm}, \beta=101.38(2) \circ$ yielding $V=202.9(2) \AA^{3}$ based on 30 single indexed lines for $\operatorname{LiLa}\left(\mathrm{CN}_{2}\right)_{2}$; and $a=541.9(1)$ pm, $b=374.50(8) \mathrm{pm}, c=1008.8(2) \mathrm{pm}, \beta=101.21(1){ }^{\circ}$ yielding $V=200.8(1) \AA^{3}$ based on 33 single indexed lines for $\mathrm{LiCe}\left(\mathrm{CN}_{2}\right)_{2}$.

\section{X-Ray Single-Crystal Diffraction}

Colourless needle shaped single-crystals of LiLa $\left(\mathrm{CN}_{2}\right)_{2}$ and orange crystals of $\mathrm{Ce}_{3}\left(\mathrm{CN}_{2}\right)_{3} \mathrm{~N}$ were selected and mounted on the tips of glass fibers for single-crystal $X$-ray diffraction measurements (Stoe, IPDS I diffractometer, graphite monochromated Mo- $\mathrm{K}_{\alpha}$ radiation, $\lambda$ (Mo$\left.\mathrm{K}_{\alpha}\right)=71.073 \mathrm{pm}$ ) performed at $210(2) \mathrm{K}$ for $\mathrm{LiLa}\left(\mathrm{CN}_{2}\right)_{2}$ and at room temperature for $\mathrm{Ce}_{3}\left(\mathrm{CN}_{2}\right)_{3} \mathrm{~N}$ (Table 1). Intensities were corrected for Lorentz factors, polarization and absorption effects by the IPDS software X-Red/X-Shape. The crystal structure solutions and anisotropic refinements of all atoms of $\mathrm{LiLa}\left(\mathrm{CN}_{2}\right)_{2}$ and $\mathrm{Ce}_{3}\left(\mathrm{CN}_{2}\right)_{3} \mathrm{~N}$ were obtained with the program SHELX-97 package [19]. Crystallographic data are given in Table 1, atom positions are listed in Table 2, and selected bond lengths are displayed in Table 3.

Further details on the crystal structure investigations can be obtained from Fachinformationszentrum Karlsruhe, 76334 Eggenstein-Leopoldshafen, Germany (fax: (+49)7247-808-666; e-mail: crysdata@fiz-karlsruhe.de on quoting the CSD number 420440 of $\mathrm{LiLa}\left(\mathrm{CN}_{2}\right)_{2}$ and CSD number 420507 of $\mathrm{Ce}_{3}\left(\mathrm{CN}_{2}\right)_{3} \mathrm{~N}$.

\section{Results and Discussion}

During the past, the synthesis of $\mathrm{Li}_{2}\left(\mathrm{CN}_{2}\right)$ has been accomplished in several ways, i.e. through ammonolysis of $\mathrm{Li}_{2}\left(\mathrm{CO}_{3}\right)$ [20, 8], from $\mathrm{Li}_{2} \mathrm{C}_{2}$ and $\mathrm{Li}_{3} \mathrm{~N}$ [21], or by reaction of $\mathrm{Li}\left(\mathrm{NH}_{2}\right)$ or 
$\mathrm{Li}_{3} \mathrm{~N}$ with melamine [17]. According to our experiments, the synthesis from $\mathrm{Li}_{3} \mathrm{~N}$ and melamine described by Becker and Jansen is a useful and time efficient route for the preparation of $\mathrm{Li}_{2}\left(\mathrm{CN}_{2}\right)$.

A selective choice of starting materials, i.e. pure rare earth trihalide and $\mathrm{Li}_{2}\left(\mathrm{CN}_{2}\right)$ is of course crucial in order to drive solid state metathesis reactions towards desired products. The employment of various compositions of these starting materials has been successfully applied to synthesize various compositions of rare earth carbodiimide compounds such as $\operatorname{RE}_{2}\left(\mathrm{CN}_{2}\right)_{3}, \operatorname{REX}\left(\mathrm{CN}_{2}\right)(\mathrm{X}=\mathrm{Cl}, \mathrm{F}), \mathrm{ARE}_{2} \mathrm{X}_{3}\left(\mathrm{CN}_{2}\right)_{2}(\mathrm{~A}=\mathrm{Li}, \mathrm{X}=\mathrm{F})$, and $\mathrm{RE}_{2} \mathrm{X}\left(\mathrm{CN}_{2}\right) \mathrm{N}(\mathrm{X}=\mathrm{Cl}, \mathrm{Br}$, I), now being attributed by the new composition $\operatorname{ARE}\left(\mathrm{CN}_{2}\right)_{2}(\mathrm{~A}=\mathrm{Li} ; \mathrm{RE}=\mathrm{La}, \mathrm{Ce})$. This composition was indeed expected to exist, not only with lithium but also with other monovalent cations. On the other hand, the carbodiimide nitride $\mathrm{RE}_{3}\left(\mathrm{CN}_{2}\right)_{3} \mathrm{~N}$ was obtained unintentionally from thermal decomposition of $\mathrm{LiCe}\left(\mathrm{CN}_{2}\right)_{2}$. Corresponding rare earth nitridoborate nitrides, e.g. $\mathrm{Ce}_{3+x}\left(\mathrm{~B}_{2} \mathrm{~N}_{4}\right) \mathrm{N}_{\mathrm{x}}$ with $\mathrm{x}=1$, 2, where synthesized under multilateral solid state metathesis conditions departing from appropriate amounts of $\mathrm{RECl}_{3}, \mathrm{Li}_{3}\left(\mathrm{BN}_{2}\right), \mathrm{Li}_{3} \mathrm{~N}$ and $\mathrm{Li}$ as reducing agent [22].

Many carbodiimide compounds appear to be thermally labile at temperatures above $600{ }^{\circ} \mathrm{C}$. This is of course one reason that these compounds can hardly be obtained from high temperature reactions of elements - but there are some exceptions [11, 23].

$\mathrm{LaCl}\left(\mathrm{CN}_{2}\right)$ was previously shown to transform into $\mathrm{La}_{2} \mathrm{Cl}\left(\mathrm{CN}_{2}\right) \mathrm{N}$ on heating up to temperatures above $750{ }^{\circ} \mathrm{C}$. A direct synthesis of $\mathrm{RE}_{2} \mathrm{X}\left(\mathrm{CN}_{2}\right) \mathrm{N}(\mathrm{X}=\mathrm{Cl}, \mathrm{Br}, \mathrm{I})$ compounds was accomplished by using multilateral metathesis reactions departing from $\operatorname{REX}_{3}, \mathrm{Li}_{2}\left(\mathrm{CN}_{2}\right)$, and $\mathrm{Li}_{3} \mathrm{~N}$, or from other combinations of compounds [10]. A similar decomposition as for $\mathrm{LaCl}\left(\mathrm{CN}_{2}\right)$ is obtained for $\mathrm{LiCe}\left(\mathrm{CN}_{2}\right)_{2}$ after being heated at temperatures around $650{ }^{\circ} \mathrm{C}$. As noted from the previous example, a decomposition of only a portion of $\left(\mathrm{CN}_{2}\right)^{2-}$ ions is the result of the reaction to yield crystalline powder and single-crystals of $\mathrm{Ce}_{3}\left(\mathrm{CN}_{2}\right)_{3} \mathrm{~N}$. A feasible solid state metathesis synthesis for this type of rare earth carbodiimide nitride compounds is at hand.

Most rare earth carbodiimide compounds known to date can be considered to contain nearly linear and nearly symmetrical $[\mathrm{N}=\mathrm{C}=\mathrm{N}]^{2-}$ ions, but there can be deviations from the ideal $\mathrm{D}_{\infty \mathrm{h}}$ symmetry in structures, frequently due to non-equivalent environments of the two terminal nitrogen atoms. Departing from the two non-equivalent bond lengths within the cyanamide molecule $\mathrm{H}_{2} \mathrm{C}-\mathrm{C} \equiv \mathrm{N}$ of roughly $131 \mathrm{pm}$ and $115 \mathrm{pm}$ we note less distinct or sometimes equivalent $\mathrm{C}-\mathrm{N}$ distances within $[\mathrm{NCN}]^{2-}$ ions of rare earth carbodiimide compounds, typically around $123 \mathrm{pm}$ as present in the structure of lithium carbodiimide. A pronounced difference was found in the $[\mathrm{NCN}]^{2-}$ ion of $\mathrm{LaCl}\left(\mathrm{CN}_{2}\right)$ with $\mathrm{C}-\mathrm{N}$ bond lengths of 120.2(6) and 125.1(6) pm, pointing out that it is difficult to make up a fixed borderline for the notation as a carbodiimide or cyanamide ion. 
The crystal structure of $\mathrm{LiLa}\left(\mathrm{CN}_{2}\right)_{2}$ resembles layers of $\mathrm{La}^{3+}$ ions and two differently aligned $\left(\mathrm{CN}_{2}\right)^{2-}$ ions, as displayed in Figure 1. A similar difference in $\mathrm{C}-\mathrm{N}$ bond lengths as in $\mathrm{LaCl}\left(\mathrm{CN}_{2}\right)$ is obtained in one of the two crystallographically distinct $[\mathrm{NCN}]^{2-}$ ions contained in the structure of $\operatorname{LiLa}\left(\mathrm{CN}_{2}\right)_{2}$, of which one set of $\mathrm{N}(1)-\mathrm{C}(1)-\mathrm{N}(2)$ bond lengths is $122.0(8)$ and 123.8(8) pm and the second set $\mathrm{N}(3)-\mathrm{C}(2)-\mathrm{N}(4)$ being 120.8(8) and 125.5(8) pm. In addition, the $\mathrm{N}-\mathrm{C}-\mathrm{N}$ bond angles of both ions are refined near $177^{\circ}$ being close to $180^{\circ}$ which is regarded for a carbodiimide ion (Table 3 ).

Lithium ions are situated in a slightly distorted tetrahedral environment of nitrogen atoms having $\mathrm{Li}-\mathrm{N}$ distances within the interval of $209-211 \mathrm{pm}$. The lanthanum ion is surrounded by eight nitrogen atoms forming a bicapped trigonal prism, shown in Figure 2, having La-N distances of $259-268 \mathrm{pm}$.

$\mathrm{Ce}_{3}\left(\mathrm{CN}_{2}\right)_{3} \mathrm{~N}$ is the first example of a rare earth carbodiimide nitride. In the light of more $\mathrm{RE}_{3}\left(\mathrm{CN}_{2}\right)_{3} \mathrm{~N}$ compounds having this composition, the structure of this compound will be presented here only briefly. The crystal structure of $\mathrm{Ce}_{3}\left(\mathrm{CN}_{2}\right)_{3} \mathrm{~N}$ was refined in the noncentrosymmetric space group $P 2_{1} 2_{1} 2_{1}$, being rare in solid state chemistry. The unit cell of $\mathrm{Ce}_{3}\left(\mathrm{CN}_{2}\right)_{3} \mathrm{~N}$ contains eight formula units, accommodating six crystallographically independent cerium ions, six independent carbodiimide anions, and two independent nitride ions (Figure 3). The two nitride ions $(\mathrm{N}(13)$ and $\mathrm{N}(14)$ ) are surrounded tetrahedrally by cerium ions with $\mathrm{Ce}-\mathrm{N}$ distances between 229.5(7) and 247.3(8) pm. These tetrahedra are interconnected in an alternating fashion by shared corners and edges to form chains parallel to the crystallographic $y$ direction. The six $[\mathrm{NCN}]^{2-}$ ions exhibit $\mathrm{C}-\mathrm{N}$ distances ranging from 121 to $125 \mathrm{pm}$, being almost linear with $\mathrm{N}-\mathrm{C}-\mathrm{N}$ angles around $179^{\circ}$ (Table 3). Environments of $[\mathrm{NCN}]^{2-}$ ions compromise more or less distorted trigonal prismatic or trigonal antiprismatic surroundings with cerium ions, all displayed in Figure 4. The six crystallographically distinct cerium ions are shown in Figure 5, with coordination numbers between seven and eight with $\mathrm{N}$ atoms of both types, $\mathrm{N}^{3-}$ and $[\mathrm{NCN}]^{2-}$. Displayed $\mathrm{Ce}-\mathrm{N}$ distances with nitrogen atoms of $\left[\mathrm{NCN}^{2-}\right.$ ions range from $250.3(8)$ to $302.6(9) \mathrm{pm}$, but there are also short contacts with carbon atoms in the order of $300 \mathrm{pm}$. Only one cerium ion $(\mathrm{Ce}(5))$ remains without a contact to a nitride ion.

Acknowledgement. Support of this research by the Deutsche Forschungsgemeinschaft (Bonn) through the project Nitridocarbonate is gratefully acknowledged. 


\section{References}

[1] Y. Hashimoto, M. Takahashi, S. Kikkawa, F. Kanamaru, J. Solid State Chem. 1995, 114, 592; Y. Hashimoto, M. Takahashi, S. Kikkawa, F. Kanamaru, Chem. Soc. Japan, Chem. Letters, 1994, 1963.

[2] Y. Hashimoto, M. Takahashi, S. Kikkawa, F. Kanamaru, J. Solid State Chem. 1996, 125, 37.

[3] M. Li, W. Yuan, J. Wang, C. Gu, H. Zhao, Powder Diffract. 2007, 22, 59.

[4] M. Neukirch, S. Tragl, H.-J. Meyer, Inorg. Chem. 2006, 45, 8188.

[5] O. Reckeweg, T. Schleid, F.J. DiSalvo, Z. Naturforsch. 2007, 62b, 658.

[6] J. Glaser, L. Unverfehrt, H. Bettentrup, G. Heymann, H. Huppertz, T. Jüstel, H.-J. Meyer, Inorg. Chem. 2008, 47, 10455.

[7] R. Srinivasan, J. Glaser, S. Tragl, H.-J. Meyer, Z. Anorg. Allg. Chem. 2005, 631, 479.

[8] L. Unverfehrt, J. Glaser, M. Ströbele, S. Tragl, K. Gibson, H.-J. Meyer, Z. Anorg. Allg. Chem. 2009, 635, 479.

[9] R. Srinivasan, M. Ströbele, H.-J. Meyer, Inorg. Chem. 2003, 42, 3406.

[10] R. Srinivasan, Dissertation, Univ. Tübingen, 2004.

[11] O. Reckeweg, F.J. DiSalvo, Z. Anorg. Allg. Chem. 2003, 629, 177.

[12] W. Liao, U. Englert, R. Dronskowski, European J. Inorg. Chem. 2006, 21, 4233; W. Liao, R Dronskowski, Z. Anorg. Allg. Chem. 2005, 631, 1953; W. Liao, R. Dronskowski, Z. Anorg. Allg. Chem. 2005, 631, 496; W. Liao, C. Hu, R. Kremer, R. Dronskowski, Inorg. Chem. 2004, 43, 5884.

[13] E. Säilynoja, M. Lastusaari, J. Hölsä, P. Porcher, J. Luminescence 1997, 210, 72; J. Hölsä, R.-J. Lamminmäki, M. Lastusaari, E. Säilynoja, P. Porcher, Spectrochim. Acta A 1998, 54, 2065; M. Takahashi, Y. Hashimoto, S. Kikkawa, H. Kobayashi, Zairyo 2000, 49, 1230.

[14] J. Sindlinger, J. Glaser, H. Bettentrup, T. Jüstel, H.-J. Meyer, Z. Anorg. Allg. Chem. 2007, 633, 1686.

[15] H. Hartmann, W. Eckelmann, Z. Anorg. Allg. Chem. 1948, 257, 18.

[16] J. Glaser, H.-J. Meyer, Angew. Chem. 2008, 120, 7658; Angew. Chem. Engl. Ed. 2008, 47, 7547.

[17] M. Becker, M. Jansen, Z. Allg. Anorg. Chem. 1998, 624, 113.

[18] WinXPow, Version 1.10: Diffractometer Software, Stoe \& Cie GmbH, Darmstadt, Germany, 2001.

[19] Sheldrick, G. M. SHELX-97: Program Package for Crystal Structure Determination, University of Göttingen, Göttingen, Germany, 1997.

[20] A. Perret, BI. Soc. Ind. Mulhouse 1933, 99, 10. 
[21] M.G. Down, M.J. Haley, P. Hubberstey, R.J. Pulham, A.E. Thunder, J. Chem. Soc., Dalton Trans. 1978, 1407.

[22] B. Blaschkowski, H. Jing, H.-J. Meyer, Angew. Chem. 2002, 114, 3469; Angew. Chem. Int. Ed. Engl. 2002, 41, 3322.

[23] J.K. Bendyna, P. Höhn, W. Schnelle, R. Kniep, Sci Techn. Adv. Mat. 2007, 8, 393. 
Table 1 Single-crystal data from structure refinements of $\mathrm{LiLa}\left(\mathrm{CN}_{2}\right)_{2}$ and $\mathrm{Ce}_{3}\left(\mathrm{CN}_{2}\right)_{3} \mathrm{~N}$.

\begin{tabular}{|c|c|c|}
\hline Empirical formula & $\operatorname{LiLa}\left(\mathrm{CN}_{2}\right)_{2}$ & $\mathrm{Ce}_{3}\left(\mathrm{CN}_{2}\right)_{3} \mathrm{~N}$ \\
\hline Formula weight / g/mol & 225.91 & 554.46 \\
\hline Crystal system & monoclinic & orthorhombic \\
\hline Space group & $\mathrm{P} 2{ }_{1} / \mathrm{m}$ (No. 11) & $\mathrm{P} 22_{1} 2_{1} 2_{1}$ (No. 19) \\
\hline \multirow[t]{3}{*}{ Unit cell dimensions /pm } & $a=542.4(2)$ & $a=672.97(9)$ \\
\hline & $b=379.16(7)$ & $b=1309.8(2)$ \\
\hline & $c=1013.0(3)$ & $c=1697.7(3)$ \\
\hline Angle ${ }^{\circ}$ & $\beta=101.35(3)$ & \\
\hline Volume $/ 10^{6} \mathrm{pm}^{3}$ & $204.26(8)$ & $1496.4(4)$ \\
\hline Z & 2 & 8 \\
\hline Temperature /K & $210(2)$ & 293(2) \\
\hline Density (calculated) $/ \mathrm{g} \cdot \mathrm{cm}^{-3}$ & 3.673 & 4.922 \\
\hline Absorption coefficient $/ \mathrm{mm}^{-1}$ & 10.285 & 17.894 \\
\hline$F(000)$ & 200 & 1928 \\
\hline Crystal description & colourless needle & orange-red needle \\
\hline Crystal size $/ \mathrm{mm}^{3}$ & $0.12 \times 0.04 \times 0.04$ & $0.24 \times 0.08 \times 0.08$ \\
\hline$\Theta$ range for data collection $/^{\circ}$ & 3.83 to 25.89 & 2.40 to 25.83 \\
\hline Index range & $-6 \leq \mathrm{h} \leq 6 ;-4 \leq \mathrm{k} \leq 4 ;-12 \leq \mathrm{I} \leq 12$ & $-8 \leq h \leq 8,-16 \leq k \leq 16,-20 \leq \mathrm{I} \leq 20$ \\
\hline Reflections collected & 2273 & 16256 \\
\hline Independent reflections & 434 & 2870 \\
\hline $\mathrm{R}_{\text {int }}$ & 0.0299 & 0.0584 \\
\hline Data / Parameters & 434 / 49 & $2870 / 236$ \\
\hline Goodness-of-fit on $\mathrm{F}^{2}$ & 1.112 & 0.998 \\
\hline$R$ indices $[I>2 \sigma(I)]$ & $\mathrm{R} 1=0.0188, \mathrm{wR} 2=0.0423$ & $\mathrm{R} 1=0.0224, \mathrm{wR} 2=0.0509$ \\
\hline $\mathrm{R}$ indices (all data) & $\mathrm{R} 1=0.0199, \mathrm{wR} 2=0.0426$ & $\mathrm{R} 1=0.0247, \mathrm{wR} 2=0.0514$ \\
\hline Largest diff. peak and hole e $\cdot \AA^{-3}$ & 1.099 and -0.909 & 1.691 and -0.892 \\
\hline CSD-Number & 420440 & 420507 \\
\hline
\end{tabular}


Table 2 Atom positions and isotropic displacement parameters $\left(\AA^{2}\right)$ of $\mathrm{LiLa}\left(\mathrm{CN}_{2}\right)_{2}$ and $\mathrm{Ce}_{3}\left(\mathrm{CN}_{2}\right)_{3} \mathrm{~N}$.

\begin{tabular}{|c|c|c|c|c|}
\hline & $x$ & $y$ & $z$ & $\mathrm{U}_{\mathrm{eq}}$ \\
\hline \multicolumn{5}{|c|}{$\operatorname{LiLa}\left(\mathrm{CN}_{2}\right)_{2}$} \\
\hline $\mathrm{La}(1)$ & $0.9832(1)$ & $1 / 4$ & $0.1934(1)$ & $0.0102(1)$ \\
\hline $\mathrm{N}(1)$ & $0.6502(9)$ & $-1 / 4$ & $0.1585(5)$ & $0.0131(9)$ \\
\hline$C(1)$ & $0.426(1)$ & $-1 / 4$ & $0.1093(6)$ & $0.014(1)$ \\
\hline $\mathrm{N}(2)$ & $0.8038(9)$ & $1 / 4$ & $-0.0658(5)$ & $0.014(1)$ \\
\hline $\mathrm{N}(3)$ & $0.7576(9)$ & $1 / 4$ & $0.4048(5)$ & $0.016(1)$ \\
\hline$C(2)$ & $0.220(1)$ & $-1 / 4$ & $0.4741(6)$ & $0.012(1)$ \\
\hline $\mathrm{N}(4)$ & $0.2071(9)$ & $-1 / 4$ & $0.3491(5)$ & $0.014(1)$ \\
\hline $\mathrm{Li}(1)$ & $0.595(2)$ & $-1 / 4$ & $0.357(1)$ & $0.020(2)$ \\
\hline \multicolumn{5}{|c|}{$\mathrm{Ce}_{3}\left(\mathrm{CN}_{2}\right)_{3} \mathrm{~N}$} \\
\hline $\mathrm{Ce}(1)$ & $0.8365(1)$ & $0.0794(1)$ & $0.3986(1)$ & $0.0138(1)$ \\
\hline $\mathrm{Ce}(2)$ & $0.6181(1)$ & $0.1212(1)$ & $0.1663(1)$ & $0.0136(1)$ \\
\hline $\mathrm{Ce}(3)$ & $0.4035(1)$ & $-0.0815(1)$ & $0.3169(1)$ & $0.0139(1)$ \\
\hline $\mathrm{Ce}(4)$ & $0.3583(1)$ & $0.2139(1)$ & $0.3328(1)$ & $0.0138(1)$ \\
\hline $\mathrm{Ce}(5)$ & $0.4149(1)$ & $0.0691(1)$ & $0.5663(1)$ & $0.0137(1)$ \\
\hline $\mathrm{Ce}(6)$ & $0.1319(1)$ & $0.2459(1)$ & $0.1101(1)$ & $0.0138(1)$ \\
\hline$N(1)$ & $0.328(1)$ & $0.0934(6)$ & $0.0578(4)$ & $0.016(2)$ \\
\hline$C(1)$ & $-0.109(1)$ & $0.4096(7)$ & $0.0107(5)$ & $0.015(2)$ \\
\hline $\mathrm{N}(2)$ & $-0.048(1)$ & $0.4150(7)$ & $0.0777(4)$ & $0.018(2)$ \\
\hline $\mathrm{N}(3)$ & $0.296(1)$ & $0.3098(6)$ & $-0.0278(4)$ & $0.016(2)$ \\
\hline$C(2)$ & $0.365(1)$ & $0.3815(7)$ & $0.0093(5)$ & $0.017(2)$ \\
\hline $\mathrm{N}(4)$ & $0.435(1)$ & $0.4531(6)$ & $0.0480(4)$ & $0.018(2)$ \\
\hline $\mathrm{N}(5)$ & $0.414(1)$ & $-0.0927(7)$ & $0.1631(4)$ & $0.022(2)$ \\
\hline$C(3)$ & $0.560(1)$ & $-0.0819(7)$ & $0.1184(5)$ & $0.017(2)$ \\
\hline$N(6)$ & $0.705(1)$ & $-0.0706(8)$ & $0.0759(5)$ & $0.028(2)$ \\
\hline $\mathrm{N}(7)$ & $0.580(1)$ & $0.1992(6)$ & $0.4597(4)$ & $0.018(2)$ \\
\hline$C(4)$ & $0.122(1)$ & $0.2219(7)$ & $0.5040(5)$ & $0.015(2)$ \\
\hline $\mathrm{N}(8)$ & $0.165(1)$ & $0.1433(6)$ & $0.4693(4)$ & $0.017(2)$ \\
\hline $\mathrm{N}(9)$ & $-0.029(1)$ & $0.2743(7)$ & $0.3490(5)$ & $0.021(2)$ \\
\hline$C(5)$ & $-0.88(1)$ & $0.2740(7)$ & $0.2804(5)$ & $0.018(2)$ \\
\hline $\mathrm{N}(10)$ & $-0.145(1)$ & $0.2747(6)$ & $0.2115(4)$ & $0.016(2)$ \\
\hline$N(11)$ & $0.125(1)$ & $0.0611(6)$ & $0.2979(4)$ & $0.017(2)$ \\
\hline$C(6)$ & $0.057(1)$ & $0.0632(6)$ & $0.2306(5)$ & $0.011(2)$ \\
\hline $\mathrm{N}(12)$ & $0.506(1)$ & $-0.0673(7)$ & $0.6631(4)$ & $0.018(2)$ \\
\hline $\mathrm{N}(13)$ & $0.394(1)$ & $0.2617(6)$ & $0.1956(4)$ & $0.018(2)$ \\
\hline $\mathrm{N}(14)$ & $0.584(1)$ & $0.0790(7)$ & $0.3006(4)$ & $0.018(2)$ \\
\hline
\end{tabular}


Table 3 Selected bond lengths (in pm), angles ( $\angle$, in ${ }^{\circ}$ ), and multiplicities in $\mathrm{LiLa}\left(\mathrm{CN}_{2}\right)_{2}$ and $\mathrm{Ce}_{3}\left(\mathrm{CN}_{2}\right)_{3} \mathrm{~N}$.

\section{$\operatorname{LiLa}\left(\mathrm{CN}_{2}\right)_{2}$}

$\mathrm{La}(1)-\mathrm{N}(1)$

259.4(3) $2 x$

$\mathrm{La}(1)-\mathrm{N}(2)$

261.4(5) 1x, 268.1(3) 2x

$\mathrm{La}(1)-\mathrm{N}(3)$

266.7(5)

$\mathrm{La}(1)-\mathrm{N}(4)$

$260.8(4) 2 x$

$\mathrm{Li}(1)-\mathrm{N}(1)$

$\mathrm{Li}(1)-\mathrm{N}(3) \quad 210.7(5) 2 \mathrm{x}$

$\mathrm{Li}(1)-\mathrm{N}(4)$

$\begin{array}{llll}\mathrm{N}(1)-\mathrm{C}(1)-\mathrm{N}(2) & 122.0(8), 123.8(8) & \angle \mathrm{N}(1)-\mathrm{C}(1)-\mathrm{N}(2) & 176.8(6) \\ \mathrm{N}(3)-\mathrm{C}(2)-\mathrm{N}(4) & 120.8(8), 125.5(8) & \angle \mathrm{N}(3)-\mathrm{C}(2)-\mathrm{N}(4) & 177.6(6)\end{array}$

\section{$\mathrm{Ce}_{3}\left(\mathrm{CN}_{2}\right)_{3} \mathrm{~N}$}

$\mathrm{Ce}(2)-\mathrm{N}(13)$

243.0(8)

$\mathrm{Ce}(3)-\mathrm{N}(13)$

247.3(8)

$\mathrm{Ce}(4)-\mathrm{N}(13)$

242.5(7)

$\mathrm{Ce}(6)-\mathrm{N}(13)$

229.5(7)

$\mathrm{Ce}(1)-\mathrm{N}(14)$

238.0(7)

$\mathrm{Ce}(2)-\mathrm{N}(14)$

$235.8(7)$

$\mathrm{Ce}(3)-\mathrm{N}(14)$

244.2(8)

$\mathrm{Ce}(4)-\mathrm{N}(14)$

239.1(8)

$\mathrm{Ce}-\mathrm{N}(\mathrm{NCN}) \quad 250.3(8)-302.6(9)$

$\mathrm{N}(1)-\mathrm{C}(1)-\mathrm{N}(2) \quad 124(1), 121(1) \quad \angle \mathrm{N}(1)-\mathrm{C}(1)-\mathrm{N}(2) \quad 178(1)$

$\mathrm{N}(3)-\mathrm{C}(2)-\mathrm{N}(4) \quad 122(1), 124(1) \quad \angle \mathrm{N}(3)-\mathrm{C}(2)-\mathrm{N}(4) \quad 178.9(9)$

$\mathrm{N}(5)-\mathrm{C}(3)-\mathrm{N}(6) \quad 125(1), 122(1) \quad \angle \mathrm{N}(5)-\mathrm{C}(3)-\mathrm{N}(6) \quad 179(1)$

$\mathrm{N}(7)-\mathrm{C}(4)-\mathrm{N}(8) \quad 124(1), 122(1) \quad \angle \mathrm{N}(7)-\mathrm{C}(4)-\mathrm{N}(8) \quad 178.8(9)$

$\mathrm{N}(9)-\mathrm{C}(5)-\mathrm{N}(10) \quad 123(1), 123(1) \quad \angle \mathrm{N}(9)-\mathrm{C}(5)-\mathrm{N}(10) \quad 179(1)$

$\mathrm{N}(11)-\mathrm{C}(6)-\mathrm{N}(12) \quad 123(1), 122(1) \quad \angle \mathrm{N}(11)-\mathrm{C}(6)-\mathrm{N}(12) 178(1)$ 


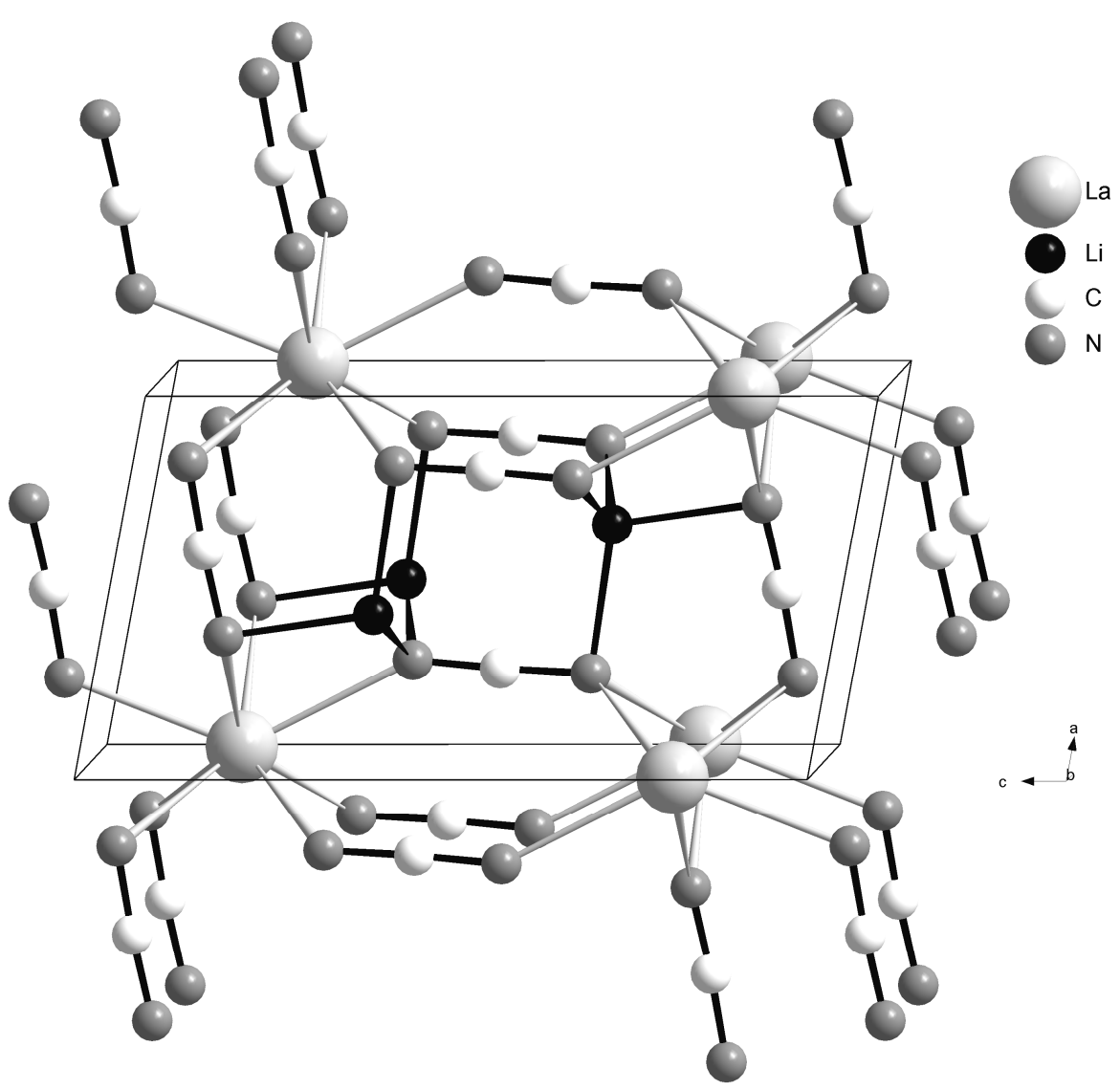

Figure 1. Monoclinic crystal structure of $\operatorname{LiLa}\left(\mathrm{CN}_{2}\right)_{2}$.

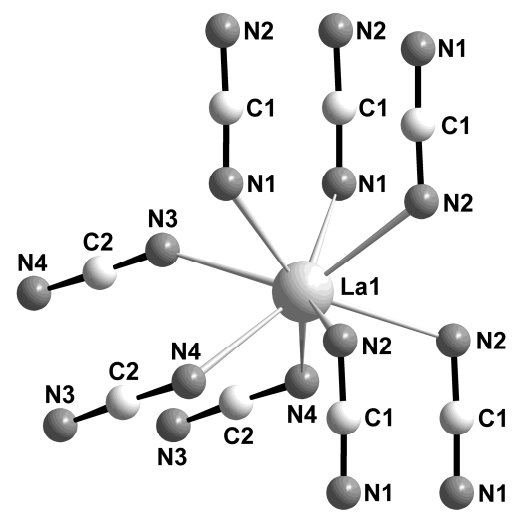

Figure 2. Environment of the lanthanum ion in $\mathrm{LiLa}\left(\mathrm{CN}_{2}\right)_{2}$. 


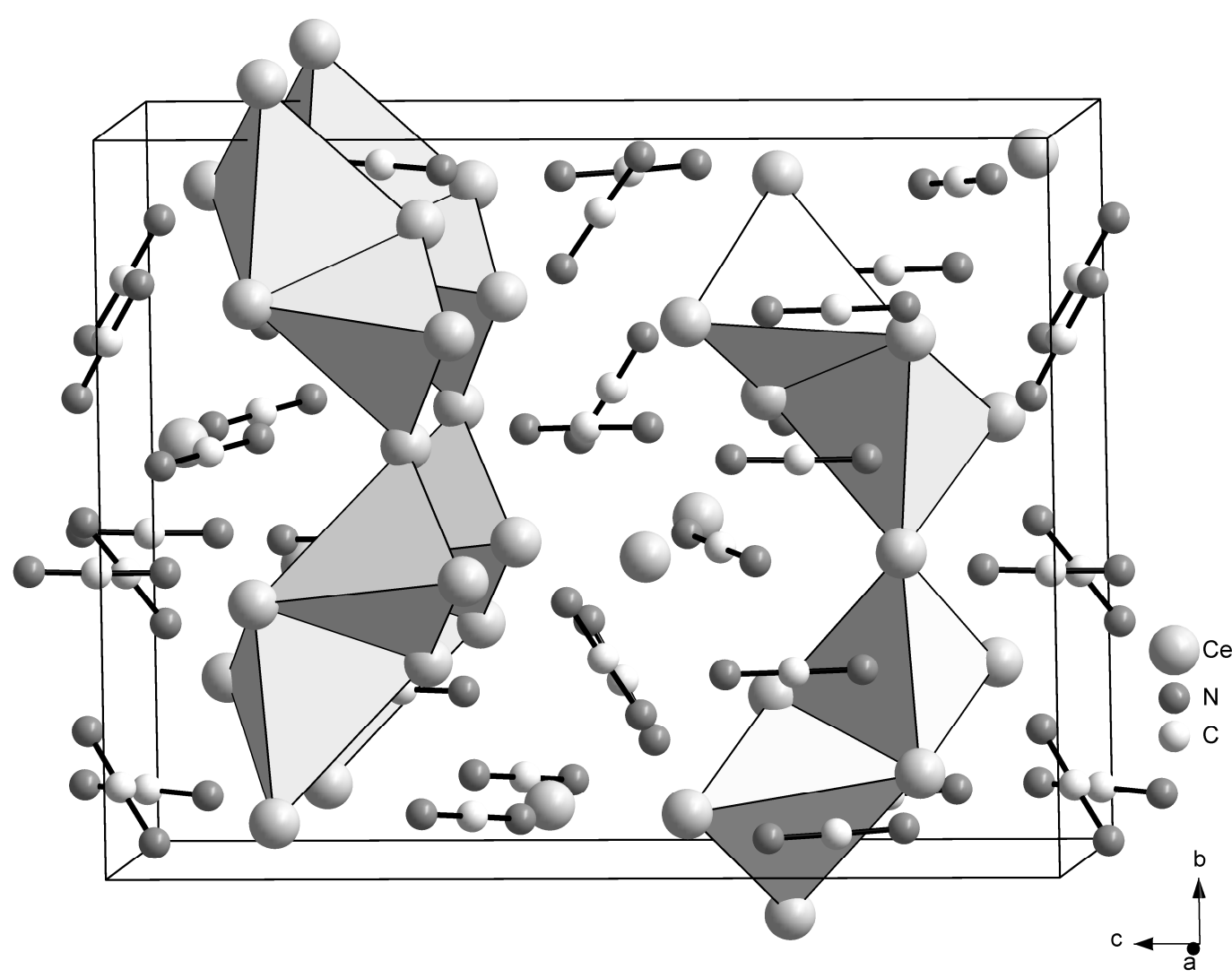

Figure 3. Orthorhombic crystal structure of $\mathrm{Ce}_{3}\left(\mathrm{CN}_{2}\right)_{3} \mathrm{~N}$.
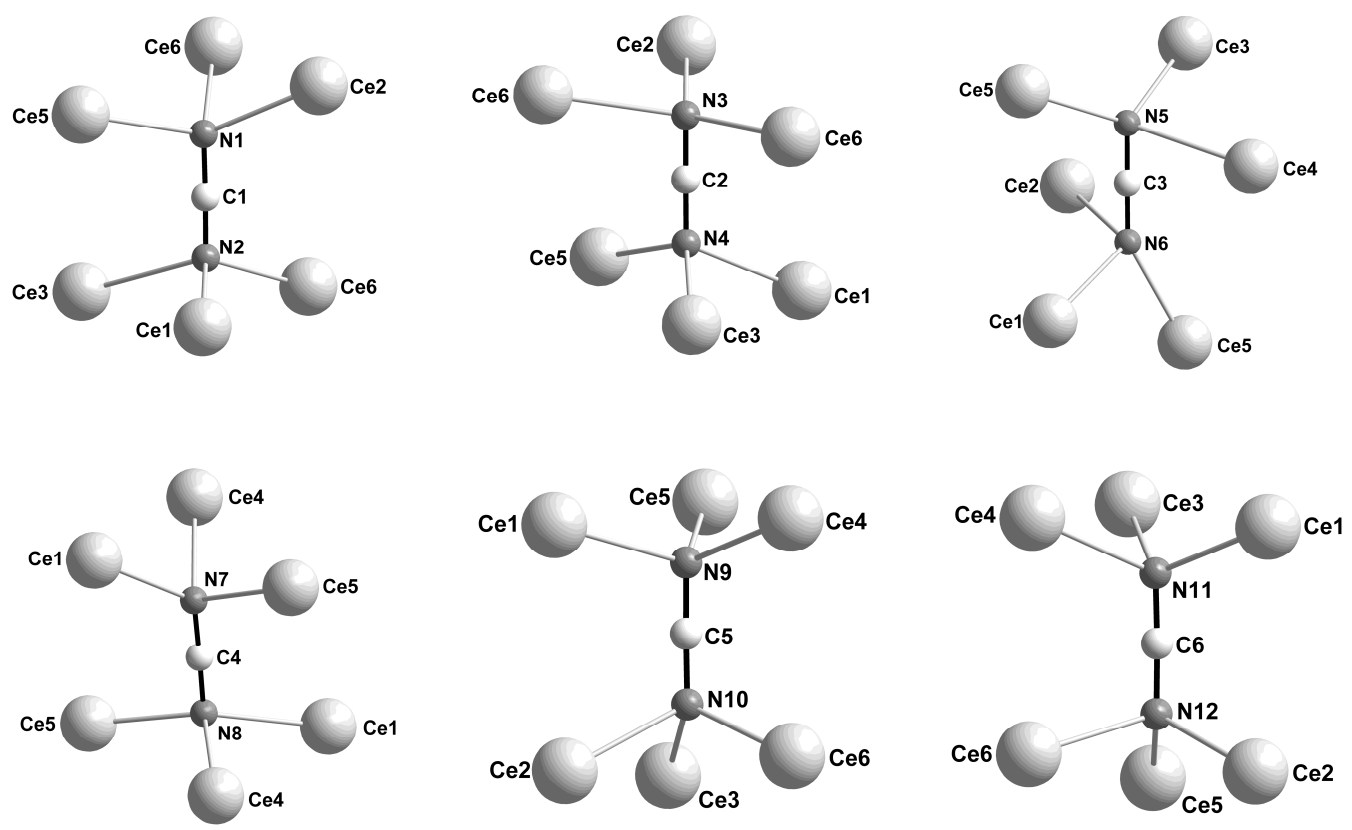

Figure 4. Environments of the six independent carbodiimide ions in $\mathrm{Ce}_{3}\left(\mathrm{CN}_{2}\right)_{3} \mathrm{~N}$. 

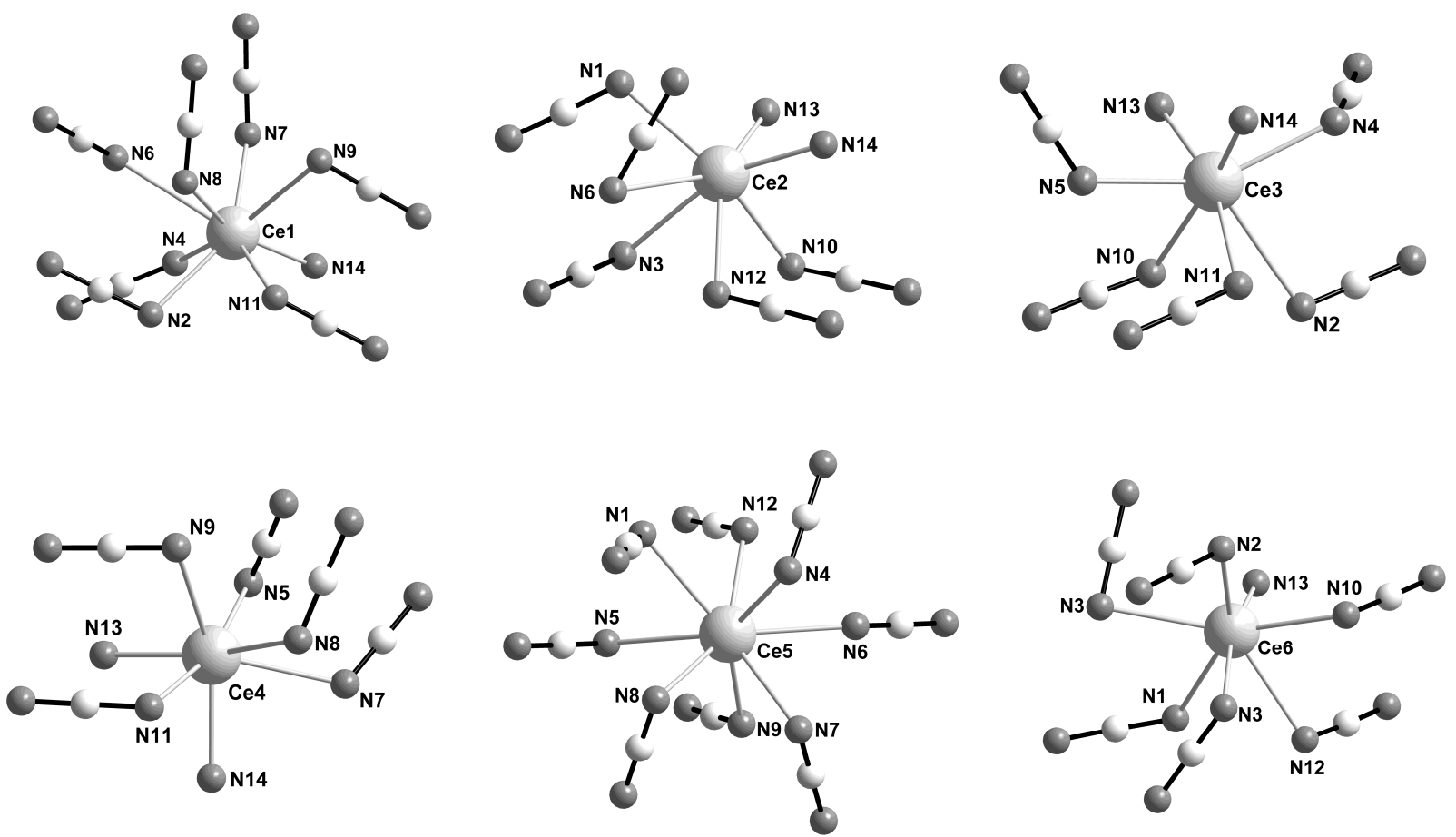

Figure 5. Environments of the six independent cerium ions in $\mathrm{Ce}_{3}\left(\mathrm{CN}_{2}\right)_{3} \mathrm{~N}$. 